\title{
No-Size-Fits-All: Collaborative Governance as an Alternative for Addressing Labour Issues in Global Supply Chains
}

\author{
Sun Hye Lee ${ }^{1} \cdot$ Kamel Mellahi $^{2} \cdot$ Michael J. Mol $^{3,5} \cdot$ Vijay Pereira $^{4}$
}

Received: 8 October 2017 / Accepted: 23 May 2019 / Published online: 18 June 2019

(c) The Author(s) 2019

\begin{abstract}
Labour issues in global supply chains have been a thorny problem for both buyer firms and their suppliers. Research initially focused mostly on the bilateral relationship between buyer firms and suppliers, looking at arm's-length and close collaboration modes, and the associated mechanisms of coercion and cooperation. Yet continuing problems in the global supply chain suggest that neither governance type offers a comprehensive solution to the problem. This study investigates collaborative governance, an alternative governance type that is driven by buyer firms setting up a coalition with competitor firms to increase leverage and address the supplier and/or host country-specific labour issues. Based on interviews with managers involved in the establishment and management of such coalitions and supplier firms in the garment industry, we examine the rationale behind collaborative governance and discuss its opportunities and challenges in addressing labour issues in global supply chains.
\end{abstract}

Keywords Coalition · Corporate social responsibility · Global supply chains · Labour issues · Global value chain · Collaborative governance

\section{Introduction}

Labour rights violations in global supply chains have been a vexing problem for buyer firms based in western countries. Existing relationships with suppliers, whether at arm'slength or through close collaboration, have failed to produce the desired solutions-considering, for instance, recent disasters in Bangladesh (Reinecke and Donaghey 2015). Media feature many stories about the exploitation of employees, under-age employment, sweat-shop labour conditions, and health and safety violations in suppliers' factories in less

Sun Hye Lee

s.lee2@lboro.ac.uk

1 School of Business and Economics, Loughborough University, Loughborough LE11 3TU, UK

2 Warwick Business School, University of Warwick, Coventry, UK

3 Birmingham Business School, University of Birmingham, Birmingham, UK

4 University of Wollongong in Dubai, Dubai, United Arab Emirates

5 Copenhagen Business School, Frederiksberg, Denmark developed countries. Yet all this negative publicity has not proved sufficient for buyer and supplier firms to resolve these problems.

Over the years, it has been evidenced that top-down approaches to controlling labour issues in supply chains are ineffective (Neef 2004; Park-Poaps and Rees 2010). The premise of relational governance has been to work with suppliers and enable them to develop the necessary capabilities to address labour issues in supply chains. Although it may be desirable and potentially effective, the relational approach can only be rolled out in a limited number of relationships due to the managerial attention and costs associated with building up such relationships, and therefore, this has apparently not been effective enough to eradicate labour issues in supply chains (Lund-Thomsen and Lindgreen 2014). Similarly, if buyers merely demand that their suppliers meet certain standards, this often does not lead to desired outcomes (Pedersen and Andersen 2006).

Acknowledging these limitations of unilateral and bilateral governance, firms have therefore scrambled to join cross-sector collaborations called multi-stakeholder initiatives (MSIs). MSIs are generally initiated and driven by societal actors and joined by stakeholders including governments, firms, trade unions and suppliers. Since their 
inception, MSIs have been considered to be a useful way to overcome the limits of unilateral and bilateral governance mainly through the combination of complementing resources and competences of participating organisations (Fransen 2011). Some MSIs focus on establishing standards and developing monitoring mechanisms, while others issue certificates and accreditations for certain qualifications (Utting 2002). Yet, of late, there have been growing concerns and critical views on the effectiveness of such a collaborative approach, although it can be hard to measure their impact and performance (Egels-Zandén and Wahlqvist 2007; Fransen and Kolk 2007; Kolk 2013).

Although traditionally buyers hold significant power over suppliers in the garment industry, some suppliers have gained more power based on their enhanced production resources and capabilities (Gereffi 2011). Therefore, switching costs for large and capable suppliers with a bigger client pool become smaller (Gereffi 2011). The interviews we present also confirm that buyer firms believe that some suppliers have gained sufficient power in supply chains to reject buyer initiatives; thus buyer firms have recently been taking an alternative collaborative approach to cultivate the necessary power and legitimacy to coerce suppliers into acting in accordance with ethical sourcing initiatives. Collective actions are actions taken jointly by buyer firms "in pursuit of the same collective good" (Marwell and Oliver 1993, p. 4), i.e., improved working conditions. So the pendulum may be swinging back from the trust-based model towards a power-based model, driven by coercion and top-down control but exercised through collaborative governance, not direct bilateral relationships. This study is prompted by the observation that buyers sharing the same supply base have been establishing coalitions to coerce suppliers to adhere to their standards.

We examine the emerging approach of collaborative governance, tackling this main question: Why and when do buyers from developed countries collaborate with peer companies? In addition, we address the possible benefits and challenges of such a model. The new approach raises novel and interesting questions for scholarly research, that go above and beyond existing scholarly work on global supply chain governance, which has mostly been focused on bilateral firm-supplier relationships, e.g. captive, relational, and modular relationships, and within-firm issues (Gereffi et al. 2005). As value chain governance not only deals with economic values but also with social values (Humphrey and Schmitz 2001), collaborative governance is an alternative way for firms to effectively govern labour issues. A main aim of our paper is to compare collaborative governance with these other, established bilateral ways of working (Gereffi et al. 2005).

This approach involves collaboration of different organisations with conflicting interests, and firms risk knowledge spillovers to competitors. Hence, additional transaction costs occur when organisations engage in collaborative governance (Nooteboom 2004). This is true for both buyer and supplier firms, hence our conceptual question is when would organisations be willing to bear such costs? This in turn begs the question what drives partnership formation with competitors, and how does such partnering affect costs (Wootliff and Deri 2001)? In our paper, which builds on interviews with managers involved in the setting-up and management of inter-firm supply-chain alliances and with suppliers based in Hong Kong and India, as well as extensive secondary data analysis, we examine the theoretical underpinnings of these coalitions and critically discuss their effectiveness in addressing labour issues in supply chains. In doing so, we later seek to reconcile our exploratory findings with the theory of value chain governance (Gereffi et al. 2005). Thus, one scholarly contribution of our study is that we contrast and compare collaborative governance with various bilateral governance modes.

Existing literature sees reputational interdependency as a strong driver of such buyer-led initiatives (BLIs) (e.g. Barnett and King 2008; Fauchart and Cowan 2014) and evaluates the effectiveness of collaborations based on factors and dynamics of the participating buyers e.g. free-riding, opportunistic behaviours (e.g. Lenox and Nash 2003; Prakash and Potoski 2007). The literature also looks at the legitimacy of BLIs as private regulations (e.g. Egels-Zandén and Wahlqvist 2007; Vogel 2008). Yet, to the best of our knowledge, there has not yet been a study into the phenomenon using the conceptual perspective of supplier governance. Filling this gap, a second contribution of our study is to the literature on CSR in global supply chains, specifically in explicating the conditions under which different governance modes are appropriate. Finally, we contribute to the theory of global value chains by highlighting an additional type of governance that, under the right conditions, is particularly useful in addressing social issues in supply chains.

This study produces relevant insights for practitioners too. Labour problems in supply chains are more than "minor upstream inconveniences" (Jiang et al. 2009, p. 169). They often receive wide media coverage and attract negative public interest. Several studies have reported that accusations of unethical practices in supply chains may lead to erosion of market positions and can result in substantial damage to brands (Emmelhainz and Adams 1999; Frenkel and Scott 2002; Nelson and Zadek 2000). Acknowledging diverse relationship dynamics in global supply chains, we provide guidelines for practitioners to refer to when they decide on the most suitable governance mode considering the power dynamics with suppliers. In pursuit of effective and efficient measures to tackle the problem, firms in a relatively weaker position could proactively form and join alliances with other firms that share the same supply base while carefully 
comparing potential opportunities and costs. Collaborative governance thus provides managers with an additional repertoire to draw upon.

We proceed with more background on buyer-supplier relationships and labour issues. Then, we introduce our empirical research method, report the findings, and end with a discussion and conclusions.

\section{Background}

\section{Buyer-Supplier Relationships and Labour Issues: Towards a New Coercive Model}

In the 1970s, the footwear and apparel industry started a trend of offshoring and outsourcing production to developing countries where abundant, cheap, low-skilled labour was available (Lim and Phillips 2008). While this reduced upstream costs, it also created a number of unintended adverse consequences, including mistreatment and exploitation of labour in supplier firms (Emmelhainz and Adams 1999). Since the early 1990s, a series of irresponsible business practices in developing countries has provoked vigorous criticism from the public and from non-governmental organisations (NGOs) (Kolk 2003). Household names, including Nike, Walmart, Gap, and H\&M, were held responsible for sweatshop conditions in factories in the developing countries where their branded goods were produced (Emmelhainz and Adams 1999; Frost and Burnett 2007). As recently as 2012 and 2013, deadly fires in several supplier factories and the collapse of the Rana Plaza complex in Bangladesh underscored the persistence of the problem (Wieland and Handfield 2013).

Firms initiated actions to combat such labour issues in supply chains from the early 1990s onwards. In 1991, Levi Strauss, followed by Nike in 1992, adopted firm-specific codes of conduct and internal audits focusing specifically on labour rights and working conditions (Murphy and Matthew 2001; Pedersen 2006; Roberts 2003; Van Tulder and Kolk 2001). This practice became widespread as other firms were subjected to strong institutional pressures (Jørgensen et al. 2003).

Simultaneously there was a growing need for universally applicable standards, such as global reporting initiatives (GRI) and the UN Global Compact. These globally applicable standards provide guidance for firms to prepare standardised codes (Albareda 2013). And the application of standards requires firm level action as firms share globally agreed codes of conduct and the implementation is still expected to be carried out by individual firms, with little need for collaboration between firms (Fransen 2011; Fransen and Kolk 2007; Lund-Thomsen 2008; Rasche 2012). Even though global standards can, albeit in a very limited way, address the issues of one-sidedness and inconsistency of corporate codes of conduct, the lack of specificity and the absence of enforcement mechanisms still remain (Fransen and Kolk 2007; Rasche 2010).

The limitations of codes, standards, and monitoring could be overcome by a relational, trust-based approach (Soundararajan and Brown 2016). Cooperation with suppliers includes ongoing two-way conversations, information sharing, and training (Andersen and Skjoett-Larsen 2009; Lim and Phillips 2008; Locke et al. 2007). The assumption here is that the proactive involvement of suppliers that strive for a long-term relationship may lead to better compliance (Dyer and Singh 1998; Lim and Phillips 2008). However, the collaborative approach is complicated by the globalization of supply chains, where buyer firms source their products from several suppliers that can be located in different countries and suppliers also serve multiple buyers (Utting 2002). This makes it costly and almost impossible to build and sustain cooperative relationships across supply chains that may include hundreds of suppliers (Lund-Thomsen and Lindgreen 2014).

In parallel, multi-stakeholder initiatives (MSIs) emerged; MSI is a broad concept and includes private organizations, i.e. firms, competitors, NGOs, and trade unions, as well as governments, and is initiated and driven by societal actors/ organisations in the majority of cases (Baur and Schmitz 2012; O'Rourke 2006; Rasche 2012). Over time, MSIs have evolved and now include a number of standards, monitoring mechanisms and accreditation for certain qualifications (Fransen 2011; Utting 2002). Representative examples of MSIs include ethical trading initiatives (ETI), FLA (fair labour association), and social accountability international (SAI). ETI is run by its membership and members adopt the ETI base code in pursuit of improvement of workers' rights (Utting 2002). FLA is driven by universities and civil society organisations aiming to resolve labour issues mainly through setting standards and conducting external audits and accrediting companies. SAI is a multi-stakeholder organisation that has established SA8000 to promote labour rights and decent working conditions around the globe. Although there are a number of MSIs, even overlapping in terms of purposes and functions, they have not fully resolved issues in global supply chains and are often criticised for the lack of enforcement mechanism and for being abstract and nominal institutions that simply issue membership certificates and accreditations (Utting 2002).

One of the main causes of continuing problems, either with corporate or global standards, is the governance of supply chains (e.g. monitoring, audits and remedial actions) that eventually boils down to individual firms. Suppliers seldom welcome investigation through audits (Morali and Searcy 2012). Audits are costly and smaller buyer firms and suppliers often do not have the financial or human resources 
needed for repeated audits (Ciliberti et al. 2011; Utting 2002). In addition, it is easy for suppliers to deceive the buyer if repeat audits take place sporadically and last only a few days (Egels-Zandén 2014; Plambeck and Taylor 2016).

Acknowledging the real-life difficulties and limitations of existing governance mechanisms, a different type of collaboration is emerging that is co-led by competing buyers in an effort to increase leverage over suppliers as well as the level of dependence by suppliers, to eventually induce a higher level of compliance and cooperation. Generally, firms enter into an alliance when they foresee a strategic or financial benefit in doing so (Kale et al. 2002), including firms in vulnerable positions (Eisenhardt and Schoonhoven 1996). Buying firms that account for only a small amount of the total production of a supplier are an example of such a position as they lack enforcement mechanisms. Thus, they ally with each other and combine their resources, relative power to the suppliers, to increase their leverage (Das and Teng 2000). For resources they cannot obtain through intrasector collaboration, they pursue cross-sector collaboration, specifically by reaching out to NGOs and accessing their expertise (Rondinelli and London 2003). As such, participating firms and NGOs complement each other in collaborative governance.

This new governance mode has been categorised as a sub category of MSI that is often called a business (or industry)-driven initiative (BDI); in this study we use the term collaborative governance to conceptually differentiate it from the other forms of MSI and to focus on its benefits and drawbacks. Collaborative governance involves multiple parties but is characterised by proactive and collective actions driven by businesses, not by societal actors/organizations. Collaborative governance is more focused in terms of attempts to address specific issues, gathering around a shared supply base rather than trying to develop a cure-all. This aims to coerce suppliers and curb their potential opportunism with very specific purposes, target suppliers/countries/issues; in so doing it is assumed that buyer firms reduce the chances that labour problems will occur, or at least lower their severity. Coercive strategies take the form of "threats, promises, and/or legalistic pleas" (Frazier et al. 1989, p.59). The assumption here is that the threat of punitive action is more effective if it comes from a collective rather than from a single firm.

\section{Method}

To understand how this collaborative governance model operates, we conducted an exploratory study. An exploratory qualitative study is appropriate, given limited existing knowledge on this topic and our focus to theorize around it, rather than formally test hypotheses. For the first phase of our study, we selected study participants, who were identified from firms that were actively engaged with collaborative governance. Firms had to meet three key criteria for inclusion in this study. First, labour issues in supply chains had to be a relevant problem for them, as expressed in the media or public debate. Second, their annual or standalone CSR reports had to demonstrate that they were actively seeking some solution(s) to address these issues. Third, they had to be a part of a formal coalition or alliance addressing labour issues in supply chains.

For our empirical investigation, we chose the retail clothes sector because of its long history with labour issues in supply chains. Clothing retailers have borne the brunt of public criticism and media scrutiny over labour issues in their suppliers' factories. The companies selected for the first phase of our research varied in size, target consumer, and ownership type, as shown in Table 1 . This diversity was intentional to enable us to capture the drivers for the formation of alliances and the differentiated impact on management of people at supplier factories. Through snowballing we included in our interviews NGOs frequently mentioned in earlier interviews with buyer firms. Given our interest in how firms seek to exploit collaborative governance, most interviews were with firm representatives.

Primary data were acquired from interviews with firm representatives in charge of CSR policies in supply chains, managers from NGOs and suppliers. Interviews were semistructured and centred on collaborative strategies to address labour issues in supply chains. The organisations and interviewees are not revealed, to protect their identity. The company names are denoted by alphabets to anonymise them (see Table 2). Extensive secondary data were collected to corroborate the interview data and included firms' archived documents, other organisations, online sources, and the media. Interviewees' responses were compared, confirmed, or challenged by these documents so we could avoid method bias through triangulation (Podsakoff et al. 2012). The sources for our data are shown in Table 3.

Thus, in phase one of our data collection process, we conducted 11 interviews with CSR/sustainable-sourcing representatives from UK and Danish retailers, a representative of an MSI and a representative of a supplier company (Hong Kong based). After an initial preliminary analysis of our data to the initial set of questions in phase 1 interesting areas emerged leading to further questions, such as: What difficulties do suppliers face in ensuring decent work; how do they experience the multiple economic and social pressures by buying companies; would suppliers welcome a changed approach where their buyers will jointly engage them? Furthermore, it made sense to corroborate the buyer-side findings with some supplier data; even though our research question focuses on buyer strategies, we wanted to rule out biases these buyers might 
Table 1 Summary of interviews (phase 1)

\begin{tabular}{|c|c|}
\hline Period & November 2014-June 2016 \\
\hline Types & Face-to-face (2), skype (4), phone (3), written (2) \\
\hline Duration (range) & $30-90 \mathrm{~min}$ \\
\hline \multicolumn{2}{|l|}{ Firms } \\
\hline Products served & Apparel, footwear, home products, food, luxury fashion \\
\hline Types & Public (3), private (3) \\
\hline Number of interviewees & 9 \\
\hline Designations of interviewees & $\begin{array}{l}\text { Director of sustainable business, head of sustainable business, head of } \\
\text { responsible sourcing, former manager of international distribution, CSR } \\
\text { program manager, former ethical sourcing coordinator, CSR manager, } \\
\text { ethical trading team }\end{array}$ \\
\hline Country & UK, Denmark, Hong Kong \\
\hline Number of employees (range) & $10,000-80,000$ \\
\hline Firm revenue (range) & $\$ 2000$ million$-\$ 10$ billion \\
\hline \multicolumn{2}{|l|}{ Non-profit enterprise } \\
\hline Description & Pursuing transparency across supply chain by implementing technologies \\
\hline Number of interviewees & 1 \\
\hline Designation of interviewee & Director/founder \\
\hline \multicolumn{2}{|l|}{ Multi-stakeholder initiative } \\
\hline Description & Providing a forum for firms, trade unions, and NGOs to share best practices \\
\hline Number of interviewees & 1 \\
\hline Designations of interviewee & China representative \\
\hline
\end{tabular}

Table 2 Characteristics of the sample companies in phase 1

\begin{tabular}{llll}
\hline Company ID & Type & Origin & Ownership \\
\hline Company A & Multinational retailer & UK & Public \\
Company B & Retailer & UK & Public \\
Company C & Luxury brand & UK & Public \\
Company D & Fashion brand & UK & Private \\
Company E & Retailer & Denmark & Private \\
Company F & Garment manufacturing & Hong Kong & Private \\
& supplier & & \\
\hline
\end{tabular}

have in reporting on a sensitive topic like this. Thus, we embarked on a second phase of data collection, where we conducted more interviews with informants from suppliers and suppliers' suppliers. The characteristics of the sample companies, data source, the list of informants/interviewees and summary of interviews in phase two is detailed in Table 4.

\section{Analysis and Findings}

Guided by the theoretical thematic analysis process suggested by Braun and Clarke (2006), the in-depth data analysis of data from both phases began with sufficiently familiarising with the collected interview data. This first step entails thorough transcription of all verbal expressions and repeated readings of the transcripts. The transcribed interview data were first coded and divided into concepts. The concepts were mostly predetermined, based on a literature review, and guided the interview processes. The concepts

Table 3 Data sources (phase 1)

\begin{tabular}{|c|c|}
\hline Data source & Details \\
\hline Interviews & $\begin{array}{l}11 \text { interviews with current/former CSR practitioners of different organisations including retail companies, NGOs, and } \\
\text { a supplier, conducted face-to-face, by Skype, telephone and written communication. Further details can be found in } \\
\text { Table } 1\end{array}$ \\
\hline Corporate reports & $\begin{array}{l}35 \text { reports published by the companies interviewed between } 2000 \text { and 2016, e.g. CSR reports, sustainability reports, } \\
\text { human rights reports, codes of conduct }\end{array}$ \\
\hline Company websites & CSR, ethical trading and partnership information available on the websites of the companies interviewed \\
\hline $\begin{array}{l}\text { Published news articles } \\
\text { and scholarly articles }\end{array}$ & $\begin{array}{l}469 \text { articles and commentaries published by the media 2000-2016, accessed from the FACTIVA database and Google } \\
\text { searches/Google Scholar }\end{array}$ \\
\hline
\end{tabular}


Table 4 Characteristics of the sample companies in phase 2

\begin{tabular}{lllll}
\hline Company ID & Type & Origin & Ownership & Designations of interviewees \\
\hline Company G & Garment material supplier & India & Private & Director of Procurement and CSR \\
Company H & Garment material supplier & US & Private & Director of Sales and CSR \\
Company I & Garment material supplier & Bangladesh & Private (family owned) & Director of Procurement and CSR \\
Company J & Garment material supplier & India/Sri Lanka & Private & CEO \\
Company K & Garment material supplier & India & Private (family owned) & Director of Business Development \\
Company L & Garment material supplier & India & Private & CEO \\
\hline
\end{tabular}

were then reorganized and regrouped as categories. The categories were chosen as they were the most predominantly and frequently mentioned aspects from the data set, which were broadly about challenges in current practices and efforts to address the issues. And they were agreed by the co-authors who independently read the data. Next, the data extracts were displayed with categories, and all extracts were compared to reveal similarities, patterns, and causality (Miles and Huberman 1994). Through this approach, four main overarching themes: drivers, implementation, implications for labour issues, and challenges, and eight sub-themes were identified. At this stage, to ensure the homogeneity of data extracts under the same themes and the heterogeneity of the different themes, there was a recursive reading back and forth between the data set and the data extracts (Patton 1990).

\section{Drivers for Collaborative Governance}

The governance of global value chains of the garment industry has been categorised into two major types; (a) the captive type where focal firms hold absolute power over suppliers and (b) the relational type where the relationship between focal firms and suppliers are established based on mutual trust (Gereffi et al. 2005). Of late, however, an increasing number of suppliers are gaining power through their competencies, and these dynamics lead to modular governance (Gereffi et al. 2005). As value chain governance includes 'how' products are made (Humphrey and Schmitz 2001), not only the transaction-specific factors but also labour issues have been dealt with mainly by the three governance modes. The analysis of the interview data reveals that the three value chain governance modes, captive, relational, and modular, are indeed of use in addressing labour issues in the garment industry supply chains as suggested by Gereffi et al. (2005) (see Table 5). However, since all of these modes are not free of limitations, buyer firms opt for collaborative governance to address two major interrelated issues: inverted power asymmetry and informational asymmetry.

\section{Power Asymmetry}

The garment industry is typically considered to be the place where captive governance is operative since a buyer has less dependence and a supplier has higher dependence on the relationship. This case might seem better, as it is now the buyer who has the power. However, all of our interviewees affirmed that simply auditing, monitoring, and enforcing buyer regulations would not improve working conditions or labour rights in factories. Continuous support and

Table 5 Governance types, characteristics, effectiveness

\begin{tabular}{|c|c|c|c|c|}
\hline & \multicolumn{4}{|l|}{ Governance types } \\
\hline & Captive & Relational & Modular & Collaborative \\
\hline \multicolumn{5}{|l|}{ Characteristics } \\
\hline Power asymmetry & High $(\mathrm{B}>\mathrm{Ss})$ & Low $(B \approx S)$ & Low $(\mathrm{Bs} \leq \mathrm{Ss})$ & High $(B s \geq S)$ \\
\hline Opportunities & High compliance & High cooperation & Low switching costs & High compliance \\
\hline Challenges & $\begin{array}{l}\text { Opportunistic behav- } \\
\text { iours of suppliers }\end{array}$ & $\begin{array}{l}\text { Difficult to develop } \\
\text { and maintain }\end{array}$ & $\begin{array}{l}\text { Low motivations for sup- } \\
\text { pliers to comply }\end{array}$ & $\begin{array}{l}\text { Difficult to reach } \\
\text { consensus among } \\
\text { buyers }\end{array}$ \\
\hline \multicolumn{5}{|l|}{ Applicability of standards and programmes } \\
\hline $\begin{array}{l}\text { Corporate } \\
\text { e.g. NIKE corporate code of conduct }\end{array}$ & High & High & Low & - \\
\hline $\begin{array}{l}\text { Global } \\
\text { e.g. SA8000, GRI, UN global compact }\end{array}$ & High & High & Low-medium & Medium \\
\hline Supplier-/issue-specific & - & High & - & High \\
\hline
\end{tabular}


communication are necessary, since otherwise the supplier might simply try to cheat and manipulate data. A supplier which is not fully convinced of the need for improvements is easily tempted toward guile instead of making efforts to address issues. As the director of sustainable business of Company A put it:

I think we need to have minimum standards. But that will never be enough to drive the transformation that we want to see... And what we found really successful is that we find ways to inspire our suppliers so that they believe this is good for their business.

The analysis of secondary data reveals that some of the firms in the study have as few as 200 suppliers and others nearly 700 (2016 CSR report, Company A; 2016 CSR report, Company D). The suppliers are dispersed around the globe, from 29 to 41 countries. Given that some big suppliers own multiple factories, the number of factory sites that require audits and monitoring increases exponentially. For example, one of the firms in our study had around 200 suppliers using 800 factory sites (2016 CSR report, Company D) and another had 662 suppliers and used 1965 factory sites (2016 CSR report, Company B). At the same time, the number of suppliers used is increasing over time. These figures do not include sub-suppliers, and the numbers will dramatically increase when taking sub-suppliers into account. According to our analysis of firms' reports, most of the firms do not fully complete annual audits for individual factory sites. Company $\mathrm{C}$, working with the smallest number of factories, claims it completed 100\% audits in 2015 (2016 CSR report, Company D), while the firm with the largest number of suppliers recorded $49 \%$ completion in the same year (2016 CSR report, Company A). Our analysis of the reports demonstrates how unlikely it is for firms to communicate with every single supplier and convince them to responsibly run their factories when they are not able to complete oneoff audits.

Moreover, considering that in most cases, the suppliers are in countries that are politically, economically, and legally less developed, interviewees reported that the problem is not always with suppliers not wanting to fix issues, but with their governments and society not pushing them or supporting them sufficiently to do so. In this case, the proactive involvement of buyers plays a more significant role. As the China representative of an NGO confirms:

Social auditing is very corruptive in China. So the idea is really to go beyond social auditing and to have really workers' engagement and invest money on capacity building instead of just monitoring repetitively and meaninglessly.

In principle, relational governance based on a cooperative relationship can reduce transaction costs and enhance value outcomes (Atrek et al. 2014; Dyer 1997; Dyer and Singh 1998; Uzzi 1997). Mutual trust and/or commitment is required for cooperation between a buyer and a supplier (Morgan and Hunt 1994). Most of the interviewees confirmed that their firms have policies to develop and help suppliers to enhance working conditions in their factories. They try to build trusting relationships by ensuring suppliers that they will not abandon the relationship, asking for commitment from suppliers in return. When they become aware of issues such as child labour, unethical behaviour or illegal discrimination, and safety violations, they give the factories time and, if necessary, resources to address them. Once there is evidence that suppliers are willing to make an effort to improve, the brands try to support them. A CSR program manager of Company B described their approach:

What we have to do is to send them a clear message that we are going to work with them. We have local teams. We are not going to charge them for all the advice and support. We do free training every month. In China, we do age verification, management systems, working hour training, all screening, every single month, in three different locations. We provide the support, the advice, the expertise, the knowledge.

Similarly, the director of sustainable business of Company A noted:

Our policy is not to just walk away from suppliers. I think there's different situations, when we check on the suppliers on board, we recognize that they will take some time to get to the standard that we want.... But as long as we can see evidence of improvement and that they share the same set of values and the same aspiration to get to the standard, we will continue to work with them because we believe that's the most responsible approach.

On a similar note, a former ethical sourcing coordinator of Company $\mathrm{C}$ reported:

We continuously work with them and talk to them face-to-face or on the phone to help them to achieve those things. It's not like we impose a policy on them. But we actually work with them all the time so they can improve themselves.

Relational governance is probably the best and ideal way to address labour issues. A brand and a supplier make attempt to work together and cooperate on a basis of mutual trust and commitment. However, this is almost exclusively possible in a relationship where both parties are highly dependent on each other. In the garment retail industry, where manufacturing requires few brand-specific skills, most suppliers serve multiple buyers, and at the same time brands are likely to source products from multiple suppliers. Therefore, rather 
than long-term relationships, we mostly find arm's-length relationships, in which either the buyer or the supplier is less dependent on the relationship, or neither party is particularly reliant on the relationship.

Perhaps surprisingly, buyer firms in the industry perceive large suppliers as having acquired substantial power over them. Large suppliers have the capacity to supply many brands simultaneously and are, therefore, less receptive to pressure from buyer firms. Switching costs are reported to be very high for buyers, because the initial investment in finding and establishing a relationship with the right suppliers is substantial (Harms et al. 2013). Unless they do invest a sufficient amount of searching costs, they are likely to end up with similar problematic suppliers (Wieland and Handfield 2013). Our respondents, therefore, challenged the notion that buyers dominate the supply chain. This is evidenced by the head of responsible sourcing of Company A:

I think where it is typically challenging is where you have no leverage. So if you buy very, very little from the supplier, it's at the very beginning of the relationship, and maybe you have been buying there for a couple of weeks, it's therefore very difficult to influence that organisation to make change happen.

Under this kind of scenario, pressure might even give the supplier an incentive to leave the relationship, as noted by the director of sustainable business of Company A:

... they [suppliers] will probably not want to supply us anyways because more and more suppliers can choose who they sell products to.

The last scenario where neither party is dependent on a relationship, which makes market governance come into play, is not discussed as a governance mode in the garment industry by Gereffi et al. 2005) but in fact common in practice. And in such relationships, addressing labour issues is rarely prioritised. When an issue is detected, the easiest and simplest option for a buyer firm is to exit the relationship. Considering the low level of dependence, finding a new supplier that has the capacity to produce the same goods is not likely to be problematic. But, as we pointed out earlier, it is highly likely that an alternative supplier's operations will have similar issues. Hence, the buyer firm has an incentive to try and find a way to address the issue and keep current relationships. However, a supplier's low level of dependence significantly reduces the supplier's incentive to comply and increases the likelihood that the supplier will exit the relationship.

One of the firms in our study reported that 38 relationships out of 1965 were terminated due to non-compliance in 2015 (2016 CSR report, Company B). Company C had to leave its Chinese supplier in 2012 when it was discovered that the supplier was exploiting workers. The supplier was producing for multiple Western customers and Company C was sourcing only $3 \%$ of the supplier's entire production, and which means low dependence from the supplier on the relationship. Neither of the two companies provided any detailed reasons for the extreme decisions in the report, but the interviews and secondary data indicate that those decisions are usually made when suppliers show little intention to address labour issues at their sites.

One of the firms reported that $80 \%$ of their products are made by the top $10 \%$ of suppliers, while they source small amounts from the rest of the suppliers (2016 CSR report, Company D) and these relationships are likely to be arm'slength, where conversation and persuasion are not likely to work. Two respondents also acknowledged that this approach is only effective with a limited number of key suppliers:

In Bangladesh, our top three suppliers are quite big. They have grown with [our organisation]. So we are a very large customer and we have been collaborating with them ever since we started going into Bangladesh. So here we have a lot of leverage. And we are not demanding or asking them to do specific things. We are having an open and honest and equal dialogue about how to improve things.

I think key suppliers, normally, they appear to be good also at CSR.

The same applies to suppliers as well. Company F in our study, a Hong Kong-based supplier, remarks in its sustainability report that it collaborates only with key clients (2016 Sustainability report, Company F). In the same sense, the interviews with suppliers also confirmed that the suppliers tend to more actively engage in the requirements from bigger buyer than from smaller ones (Company I, J, K).

Power asymmetry is more pronounced with relatively small buyer firms. Even though one of the firms in our study is a well-established and well-known brand, some of its larger suppliers consider it a small buyer, and it, therefore, has little power over them. As the director of sustainable business in Company A stated:

The challenges are though [our firm] like many retailers has very few sites where we are the only or a very significant customer. In most sites we are one of many customers....

Similarly, one of our interviewees, a former ethical sourcing coordinator of Company $\mathrm{C}$, stressed the difficulty of applying power:

We are just a tiny company so we have to work with so many different brands to achieve some common goal.

For these firms overcoming power asymmetry and enforcing practices on suppliers can only happen if buyers using the same suppliers come together to collaborate, to increase 
the level of suppliers' dependence, and consequently exert leverage over them.

Considering that high dependence on the relationship is likely to induce cooperative strategies while low dependence makes a party less cooperative, the dependence of suppliers matters more than the level of buyers' dependence on the relationship, which challenges the common belief that buyers always play a decisive role. Although game theory suggests that through repetition of the same games parties would eventually learn that cooperation gives them higher pay-offs (Axelrod 1984; Jones 1995), in the global garment industry, where buyers and suppliers have to take care of multiple relationships dispersed across countries, such focused repetition between the two parties is not a viable option. In short, bilateral governance, either captive or relational and of course market governance, could not be expected to resolve problems with CSR in most of the relationships we looked at.

Having realised the limitations of governing global supply chains individually, buyer firms have come up with an idea for a new kind of collaboration, in the form of collaborative governance. By forming an inter-firm alliance, firms access the resource that are not available otherwise (Eisenhardt and Schoonhoven 1996), relative power over supplier. This type of governance is therefore expected to be especially useful for the firms that are facing difficulties since suppliers are not sufficiently dependent on the relationship. Firms in alliance now can integrate their power and ultimately increase their leverage (Das and Teng 2000). This move to collaborative governance is prompted by the need to shift power from suppliers to buyers, as this at least promises the second-best result.

\section{Information Asymmetry}

Interviewees confirmed that suppliers have better and more information about what goes on in their factories than buyers. A number of factors cause this information asymmetry. Interviewees suggested that suppliers have an information advantage because of geographical distance and the lack of transparency in information process across supply chains where critical information is often withheld. Respondents also frequently cited the cost associated with acquiring information. Our interviewees reported that buyer firms allocated limited budgets to CSR issues in the supply chain. For instance, the former ethical sourcing coordinator of Company C told us:

Sometimes we want to visit the place and it's too far and we don't have enough budget, so we cannot go and talk to them. So it can lead to communication breakdown because we cannot communicate with them. It's too far. We cannot see them and we cannot see the farms and actual factories.'

Physical distance generates problems even when a brand has power over a supplier. Most interviewees expressed concerns about short-burst audits and said they distrusted them, as they are considered to be little more than box-ticking exercises, with limited understanding of suppliers' day-to-day activities. The China representative of the NGO said:

Audits will always be a snapshot of the day and it is not a tool for improvement, it is a tool for control. Not only are audits incapable of capturing actual practices, but also the results are sometimes not trustworthy for deeply rooted, country-specific factors.

In addition to suppliers withholding information, interviewees reported that cultural issues lay behind some of the problems with information asymmetry. Most suppliers are based in Asian countries where people are more hesitant to bring bad news, and in order to save face tend not to discuss what went wrong and what caused failure at suppliers' factories. The China representative of a NGO said:

...[T]hat makes it more difficult to try and find causes and therefore come up with good solutions. So these are some of the challenges especially around issues around safety or worker conditions.... We recommend [our] members not to do the social auditing repetitively. ... [A]uditing is very corrupted in China.

Data also suggest that buyers and suppliers both suffer from audit fatigue. Constrained by limited resources, buyer firms have to conduct audits on multiple suppliers' operations and at the same time suppliers have to go through several buyer audits. This creates additional costs at both ends. Individuals involved in audits are often bogged down with paper work, with little insight into the real working conditions of suppliers. Through collaborative governance, firms can access information that other firms have on labour practices in a shared supply base, which saves costs for participating firms. The CSR programme manager of Company B explains that collaborative governance could have an impact on reducing the number and frequency of excessive and unnecessary audits while increasing the effectiveness of them:

Why are we all having our own audits? Why are some factories being audited 10-15 times a year? But the auditors, they have a checklist where $95 \%$ of the questions are the same. Why not have system where we all trust one type of audit and then leave the factories in peace to develop, instead of just taking days out of the calendar for audits so many times a year?...It is about sharing. It's the key 


\section{Implementation}

There is consensus among our interviewees that brands alone cannot solve labour issues in supply chains. They need assistance from a party that specializes in local contexts and specific issues. As a result, they need NGOs in a inter-firm coalition, but acting as complementors instead of initiators. The aim is to combine complementary resources, meaning the brands' financial muscle with NGOs' knowledge and experience in dealing with labour issues. (Rondinelli and London 2003). There is a strong belief that such joint approaches will ultimately address labour issues by coercing particular suppliers, industries, and even governments, into action. As a former ethical sourcing coordinator of Company $\mathrm{C}$ noted:

We will work with other brands. So we will find out if other brands are using the supplier as well. And then we will try to have a meeting with other brands and the supplier together. And then we will also ask an NGO to join because they are the third party and they can give some fair comments and they know a lot about that specific issue.

Tasks once performed by buyer firms are now allocated to NGOs. For instance, firms in our study partner with one NGO to carry out employee surveys at suppliers' factories. One of the interviewees explained that her organisation uses the services of the NGO whenever there is a need to obtain information directly from workers, to avoid workers being forced into cooperation or being manipulated by factory owners. The NGO has developed a platform to approach and contact workers outside factories, using text messages or landlines at home, to obtain a realistic picture of working conditions. Data are also collected via questionnaires sent via mobile phones provided by the NGO that are not accessible by suppliers' management. This may alleviate employees' concerns about retaliation from their employers. The director of the NGO argued that the brands that sign up for this service are those that are most dedicated to resolving issues. This service helps these brands to identify issues and put into place appropriate measures to address them, before they lead to major incidents.

Brands have also been working with multiple NGOs when problems are observed in their supply chains. For example, when one of the firms in our study found out that children were employed in the manufacturing of clothes for its brand, instead of cancelling the contract or dissuading the supplier from using under-age workers, they asked a partner NGO to step in. Thanks to its expertise and embeddedness in the local institutional context, the NGO was able to provide a holistic solution that not only enables the children to go to school, but also supports the family for loss of income.
Representatives of firms in the alliance meet regularly to address the social issues they face. The aim is to agree on common ways to approach these challenges and interact with shared supply base. The process is described by an NGO representative:

They need to bring together all the brands sourcing from the same factory to deliver that message and use that leverage to influence their suppliers. So they need some kind of common action and consistency on issues. ... It's much stronger than only for example a small brand to deliver a single message to a single supplier. It's really to maximize the leverage of the whole industry to influence suppliers in a country.

\section{Implications}

Social issues are complex, especially in multi-level global supply chains (Selsky and Parker 2005). Under some circumstances collaborative governance involving multiple buyers and other parties can be an effective alternative for tackling the issues, because (a) buyers exchange knowledge on shared supply base; and (b) they circumvent problems with limited or one-sided dependence in supply chains.

One of the biggest benefits of collaborative governance is that participating companies can share information on labour practices of shared suppliers. The largest UK retailers (including a firm in our study), came up with an idea to establish a platform named Supplier Ethical Data Exchange (SEDEX) where brands can share audit information about suppliers and effectively reduce audit fatigue. As the head of responsible sourcing of Company A explains:

'We've got a problem of audit duplication, let's invite couple of other key retailers to help us how we address that'. And that's what led us to the formation of SEDEX.

In their 2017 annual report, SEDEX highlights the significant achievement in terms of the increased identification and sharing of information on risky practices of suppliers (Sedex 2017). Yet, SEDEX is about more than just sharing information. Using the information available through the SEDEX platform, firms can initiate collaboration as they now know who else is using the same suppliers. Again, the head of responsible sourcing of Company A explained the usefulness of SEDEX:

If it's an expensive change, it's not easy to influence that if the expensive change is going to be significantly more than the profit they are going to make on making the product. So that's why we work with the organisations like SEDEX where you can get other purchasers who are also purchasing from that same site to perhaps influence the owner to make the change. 
Fair factories clearinghouse (FFC) works in a similar way but is driven by US retailers. FFC has focused on developing sophisticated methods to monitor and manage compliance and ultimately aims to use the combined leverage to enhance practices in the shared supply base.

The impact of collaborative governance can go beyond influencing suppliers. Labour issues are often not caused by suppliers but by underpinning country level institutional characteristics (Fransen 2013). Often national institutions supersede regulations established by private firms and/or MSIs (Utting 2002). As such, one further role of a coalition is to lobby governments. Fundamental changes in labour practices can only be expected when national institutions change (Utting 2002). All of the buyer firms we interviewed confirmed and emphasized the importance of their coalition in influencing a range of stakeholders in their suppliers' home countries. The CSR manager of Company A noted:

If a coalition that is representing a large part of the country's export goes to the government of course they can't and will not just act exactly as industry is telling them but it has of course some influence on how they will make decisions in the future. ... We have cosigned letters to the Bangladeshi government. I know the delegations have gone there also with brand representatives, and the minimum wage has been raised. I think $60 \%$ or something. Of course then everything else also gets more expensive. House rent, food, everything. But it has an influence, of course it has that.

Similarly, the CSR programme manager of Company B and the head of sustainable business of Company A told us:

If you look at collaboration, as brands, who has economic power? The brands. We do. We have the money; we have the resource; we are the catalyst to make this happen. If we come together, strategically, collaboratively. How many billions do you think the brands source from the countries? You think they don't have influence, leverage? Of course, they do.

We learn together, we increasingly work together, ... so together we are stronger. ... What I am saying is things can change. If you really want to you can change. What it requires is brands come together....

Table 5 enables a comparison between the different governance types that exist in the garment industry and draws on the work of Gereffi et al. (2005). Gereffi et al. (2005) describe three types of bilateral governance; we describe each of these and contrast them with collaborate governance as found in our exploratory study above. Under captive governance, focal firms can use their own codes of conduct and/or adopt global standards established by reputable organisations. Due to the power dynamic favouring buyers, the level of compliance with standards and policies is likely to be high, although there still is a chance that suppliers will act in an opportunistic way, taking advantage of physical distance and infrequent audits.

Although it is difficult to achieve, once the relationship between a buyer and a supplier is built on a solid foundation, the supplier tends to adhere to standards. The buyer and supplier could even jointly develop and tailor standards and programmes. This is a good way of dealing with labour issues in global supply chains if firms are willing to bear the setup costs.

On the other hand, the relative power of some large and highly capable suppliers tends to be stronger as is the case in modular governance (Gereffi et al. 2005), and stronger suppliers are less likely to be responsive to buyers' requirements, and compliance with individual corporate code of conduct is likely to be lower (Handfield and Bechtel 2002).

Transitions from captive to modular governance are largely determined by transaction-relevant factors including complexity and codifiability of transactions and suppliers' capabilities (Gereffi et al. 2005). However, as detailed in this paper, firms have been engaging in a different kind of governance mode to tackle social issues in global supply chains. In collaborative governance, where focal firms combine their resources, it is less likely that participating companies choose to apply the code of conduct of one of the participants; instead they design new standards (specifically designed for the supplier/country) or use existing global standards. For example, the business social compliance initiative (BSCI), a coalition exclusively open for buyers, decided to create a more specific but harmonised code of conduct, using global standards such as ILO conventions only as a guideline (Egels-Zandén and Wahlqvist 2007; Fransen 2011). In practice, the compliance level of the suppliers under the influence of BSCI has shown significant improvement (Hogstetter and Mueller 2013).

\section{Challenges}

One of the interviewees, a manager of Company $\mathrm{K}$, confirmed that the company is part of collaborative governance and sees it positively as it 'makes good business sense'. Yet, the shifting approach we describe here is not without downside risks. First, buyers participating in such partnership are likely to have different contract details with the shared suppliers. Balancing confidentiality with appropriate disclosure of competitive information such as price structures and product quality. Buyer firms negotiate different contracts with suppliers. This affects the level of information sharing between buyer firms. As a former ethical sourcing coordinator of Company C put it: 
And actually the difficult thing is with other businesses, we cannot share everything with each other. There's always this question, 'How much should we share with other brands?' It creates difficulty in achieving a common goal of trying to be more sustainable or environmentally friendly, or more ethical. So that's the challenge.

The issue with confidentiality could also be a problem between firms and NGOs in cases where NGOs are invited to join, considering that they have fundamentally different agendas (Rivera-Santos and Rufín 2010). In order for firms to be open to NGOs about their problems with suppliers, there should be a belief that such information will not be used to attack them (Rivera-Santos and Rufín 2010; Rondinelli and London 2003). At the same time, for NGOs to participate, they should believe that involvement will not harm their reputation (Rondinelli and London, 2003). Thus, mutual trust among participating organisations is crucial for the success of collaborative governance.Furthermore "a chain is only as strong as its weakest link." Differences in the levels of motivation and expectation of buyers joining the coalition pose another major challenge. Those at the higher end with large margins are willing to tolerate an increase in labour costs, while those with low margins are more sensitive to increases in the cost of labour. These differences tend to drive firms in the coalition toward the lower standards as such different levels of commitments from parties in a relationship could cause lowered productivity of the alliance (Rondinelli and London 2003). A CSR programme manager of Company B observed:

Because you've got 10 companies in a room and five of them want to do something good, three of them say, 'Okay, whatever', and one of them only wants to do this much. You can only do as much as the one that says 'I wanna do this much.' So they only do what the lowest wants.

When it comes to the governance of supplier practices, the collective coercive approach helps to push through uniform regulations and standards, which reduces suppliers' ability to resist buyer firms' demands, but at the same time heightens suppliers' perceived sense of unfairness. Thus, coercion has the potential to provoke invisible resistance from suppliers. For instance, because of fear of retaliation or termination of contracts, instead of engaging openly in discussions of buyer firms' demands that would benefit both parties, suppliers may revert to well-documented window-dressing strategies. Lastly, issues related to sub-suppliers are not explicitly addressed in the collaborative governance model. Even suppliers in our interviews which agree that collaborative governance works, find controlling sub-suppliers challenging. Most interviewees state that they are required by buyers to ask sub-suppliers to meet the same standards but do not monitor them due to the lack of coordination and resources. This calls for further research to examine the real impact of the emerging approach on labour practices at sub-suppliers.

\section{Discussion}

Given the significant impact of negative publicity that can result from labour-related issues in the supply chain, firms engaged in offshore outsourcing are developing new ways to ensure that their suppliers' activities are consistent with buyer stakeholder expectations, as expressed in policies and procedures. Our evidence suggests that firms are increasingly moving from bilateral governance, through either coercion or cooperation, towards collective coercion characterized by collaboration with competitors and NGOs. But to date there have been few academic studies of this collaborative governance model.

In this paper we have explored the reasons why firms from developed countries choose to manage their suppliers in developing countries through collaborative governance, the use of a coalition of competitor firms and/or third-party organisations, to alleviate negative labour conditions in sourcing factories. Although this is a buyer strategic choice, we also looked at the phenomenon from the supplier side to corroborate the evidence. Our findings indicate that both buyers and suppliers see significant evidence there are conditions under which neither the previous arm's-length, top-down approach of coercion nor the trust-based cooperative approach effectively addresses the underlying causes of the problem. From the buyer side collaborative governance is expected to offer an additional mechanism that can help address labour issues at suppliers' factories. Although buyers also acknowledge the challenges that the governance mode faces in practice, the data analysis highlights that implementation can lead to positive outcomes.

The bilateral governance model is bounded by several limitations. First, the trust-based cooperative approach is theoretically the best option for firms in managing labour issues with suppliers as cooperation leads to less monitoring, more compliance, and enhanced performance outcomes (Dyer and Singh 1998; Uzzi 1997). Yet, in practice, our analysis suggests that firms, at least those in the garment industry, are not capable of developing such relationships with all suppliers due to the high number of suppliers with short contract periods or low sourcing value. Our analysis shows they only can maintain such relationships with a small number of key suppliers. Theoretically, the top-down approach is only effective when the buyer is less dependent and, therefore, possesses more power (Emerson 1962), and empirically, this study confirms that serious labour issues are likely to occur when the level of suppliers' dependence is low. 
Collaborative governance not only helps to exchange knowledge and develop best practices but is also a more effective means of coercing shared suppliers into action and instigating their cooperation, because of greater bargaining power and the reduction of costs due to fewer audits (Das and Teng 2000; Eisenhardt and Schoonhoven 1996). On top of the increased power, our study further suggests that another critical advantage of collaborative governance is to stimulate discussion and knowledge-sharing among buyer firms (Rondinelli and London 2003). This can result in the pooling of resources to address labour issues.

Our interviewees did not have coherent policies to address the underlying causes of labour issues in the supply chain, beyond lobbying key stakeholders, such as local governments, persuasion, collaboration with suppliers, collective threats, and forceful coercion. The question of the extent to which collaboration and coercion mechanisms can really be distinguished from each other provides an interesting avenue for future theoretical and empirical research. We would expect collective coercion to weaken collaboration between buyers and suppliers. Furthermore, suppliers could counteract increased dependence on buyer firms by moving up the value chain and becoming direct competitors. An increase in disposable income in emerging economies is already making major suppliers in developing countries less reliant on western markets, and some suppliers are increasingly producing and selling their own branded goods (Wan and Wu 2017).

We observe that the new approach will enable buyer firms to increase their leverage based on the increased relative power and more abundant and more accurate information about labour practices, and suppliers may cooperate as they see the governance mode makes business sense. But this may not necessarily result in improvement in workers' conditions since the problem of enforcement remains along with the challenges associated with the management of the partnerships between buyers and NGOs. Acknowledging this limitation, the collaborative approach does not aim to substitute relational governance. Firms in our study are not letting go of the cooperative approach just yet. Interviewees indicated that continuous conversation is still an ideal way to make changes and convince suppliers that the new approach will eventually benefit them. This would enable them to overcome the limitations of top-down unilateral compliance. Using threats, such as termination of contracts, was not emphasized, but the importance of the suppliers making sense of improvements, as well as the effectiveness of conversations and persuasion, were stressed.

This study acknowledges the challenges faced by the practitioners who are willing to tackle the labour issues both internally as well as externally. Those practitioners fighting against the external difficulties such as institutional distance and lack of cooperation from suppliers are also fighting internally for more resources and monetary supports from firms. We provide pragmatic solutions for those managers in small buying firms by suggesting that they should collaborate with other buyers and address issues hand in hand by increasing overall leverage.

Like any empirical work, our study has some limitations. Our conceptual model only applies to the case where buyers are willing to tackle the labour issues in their supply chains even in the case where they are smaller (not in terms of absolute size, but in terms of relative size of transactions compared with other buyers or compared to the entire production of a supplier), therefore, less powerful than supplier, which means it is hard to generalise the findings to a wider population. As there cannot be one size that fits all, the collaborative governance is suggested as one of the ways of dealing with labour issues. Furthermore, because there is still only limited evidence about the effectiveness of this approach, we focused more on the principles of this shifting approach, rather than its detailed practices. We believe there is room for more structured and larger-scale research efforts. For instance, it could be helpful to survey a larger number of firms on their use of bilateral versus collaborative governance mechanisms, and how this relates to CSR outcomes.

\section{Conclusion}

Labour issues in global supply chains have remained unresolved for some decades now,. In this study, we have sought to identify the factors driving buyers to join forces, as well as collaborate with NGOs, in addressing labour issues in suppliers' operations. In so doing, we identified some root causes of failure in bilateral governance, both arm's length and relational, and the extent to which a collaborative governance approach offers more practical and effective solutions to these issues. Our findings suggest that coercive collaborative governance driven by buyers and practiced through inter-firm-NGO coalitions can potentially provide better solutions, because it increases supplier dependence in relationships, enables buyers to share critical information, leads to more effective supplier relationship management, and may eventually enable higher levels of compliance. By exploring collaborative governance as a new approach in managing CSR in global supply chains, this research contributes to the ongoing discussions on CSR in supply chains.

Open Access This article is distributed under the terms of the Creative Commons Attribution 4.0 International License (http://creativeco mmons.org/licenses/by/4.0/), which permits unrestricted use, distribution, and reproduction in any medium, provided you give appropriate credit to the original author(s) and the source, provide a link to the Creative Commons license, and indicate if changes were made. 


\section{References}

Albareda, L. (2013). CSR governance innovation: Standard competition-collaboration dynamic. Corporate Governance, 13(5), 551-568

Andersen, M., \& Skjoett-Larsen, T. (2009). Corporate social responsibility in global supply chains. International Journal of Life Cycle Assessment, 14(2), 75-86.

Atrek, B., Marcone, M. R., Gregori, G. L., Temperini, V., \& Moscatelli, L. (2014). Relationship quality in supply chain management: A dyad perspective. Ege Academic Review, 14(3), 371-381.

Axelrod, R. (1984). The evolution of cooperation. New York: Basic Books.

Barnett, M. L., \& King, A. A. (2008). Good fences make good neighbors: A longitudinal analysis of an industry self- regulatory institution. Academy of Management, 51(6), 1150-1170.

Baur, D., \& Schmitz, H. P. (2012). Corporations and NGOs: When accountability leads to co-optation. Journal of Business Ethics, 106(1), 9-21.

Braun, V., \& Clarke, V. (2006). Using thematic analysis in psychology. Qualitative Research in Psychology, 3(2), 77-101.

Ciliberti, F., de Haan, J., de Groot, G., \& Pontrandolfo, P. (2011). CSR codes and the principal-agent problem in supply chains: Four case studies. Journal of Cleaner Production, 19(8), $885-894$

Das, T. K., \& Teng, B.-S. (2000). A resource-based theory of strategic alliances. Journal of Management, 26(1), 31-61.

Dyer, J. H. (1997). Effective interfirm collaboration: How firms minimize transaction costs and maximize transaction value. Strategic Management Journal, 18(7), 535-556.

Dyer, J. H., \& Singh, H. (1998). The relational view: Cooperative strategy and sources of interorganizational competitive advantage. Academy of Management Review, 23(4), 660-679.

Egels-Zandén, N. (2014). Suppliers' compliance with MNCs' codes of conduct: Behind the scenes at Chinese toy suppliers. Journal of Business Ethics, 75(1), 45-62.

Egels-Zandén, N., \& Wahlqvist, E. (2007). Post-partnership strategies for defining corporate responsibility: The business social compliance initiative. Journal of Business Ethics, 70(2), 175-189.

Eisenhardt, K. M., \& Schoonhoven, C. B. (1996). Resource-based view of strategic alliance formation: Strategic and social effects in entrepreneurial firms. Organization Science, 7(2), 136-150.

Emerson, R. M. (1962). Power-dependence relations. American Sociological Review, 27(1), 31-41.

Emmelhainz, M. A., \& Adams, R. J. (1999). The apparel industry response to "sweatshop" concerns: A review and analysis of codes of conduct. The Journal of Supply Chain Management, 35(3), $51-57$.

Fauchart, E., \& Cowan, R. (2014). Weak links and the management of reputational inerdependencies. Strategic Management Journal, $35,532-549$

Fransen, L. (2011). Why do private governance organizations not converge? A political-institutional analysis of transnational labor standards regulation. Governance, 24(2), 359-387.

Fransen, L. (2013). The embeddedness of responsible business practice: Exploring the interaction between national-institutional environments and corporate social responsibility. Journal of Business Ethics, 115(2), 213-227.

Fransen, L. W., \& Kolk, A. (2007). Global rule-setting for business: A critical analysis of multi-stakeholder standards. Organization, 14(5), 667-684.

Frazier, G. L., Gill, J. D., \& Kale, S. H. (1989). Dealer dependence levels and reciprocal actions in a channel of distribution in a developing country. Journal of Marketing, 53(January), 50-69.
Frenkel, S. J., \& Scott, D. (2002). Compliance, collaboration, and codes of labor practice: The Adidas connection. California Management Review, 45(1), 29-49.

Frost, S., \& Burnett, M. (2007). Case study: The Apple iPod in China. Corporate Social Responsibility and Environmental Management, 14, 103-113.

Gereffi, G. (2011). Global value chains and international competition. The Antitrust Bulletin, 56(1), 37-56.

Gereffi, G., Humphrey, J., \& Sturgeon, T. (2005). The governance of global value chains. Review of International Political Economy, 12(1), 78-104.

Handfield, R. B., \& Bechtel, C. (2002). The role of trust and relationship structure in improving supply chain responsiveness. Industrial Marketing Management, 31(4), 367-382.

Harms, D., Hansen, E. G., \& Schaltegger, S. (2013). Strategies in sustainable supply chain management: An empirical investigation of large German companies. Corporate Social Responsibility and Environmental Management, 20, 205-218.

Hogstetter, J. S., \& Mueller, M. (2013). Achievement study: 10 years of the BSCI. Brussels: Business Social Compliance Initiative.

Humphrey, J., \& Schmitz, H. (2001). Governance in global value chains. IDS Bulletin, 32(3), 19-29.

Jiang, B., Baker, R. C., \& Frazier, G. V. (2009). An analysis of job dissatisfaction and turnover to reduce global supply chain risk: Evidence from China. Journal of Operations Management, 27(2), 169-184.

Jones, T. M. (1995). Instrumental stakeholder theory: A synthesis of ethics and economics. Academy of Management Review, 20(2), 404-437.

Jørgensen, H. B., Pruzan-Jørgensen, P. M., Jungk, M., \& Cramer, A. (2003). Strengthening implementation of corporate social responsibility in global supply chains. Washington, DC: World Bank Group.

Kale, P., Dyer, J. H., \& Singh, H. (2002). Alliance capability, stock market response, and long-term alliance success: The role of the alliance function. Strategic Management Journal, 23(8), $747-767$.

Kolk, A. (2003). Trends in sustainability reporting by the fortune global 250. Business Strategy and the Environment, 12, 279-291.

Kolk, A. (2013). Partnerships as a panacea for addressing global problems? Social Partnerships and Responsible Business: A Research Handbook (January 2013), 15-43. http://www.amazon.com/Socia 1-Partnerships-Responsible-Business-Research/dp/0415678633.

Lenox, M. J., \& Nash, J. (2003). Industry self-regulation and adverse selection: A comparison across four trade association programs. Business Strategy and the Environment, 12(6), 343-356.

Lim, S. J., \& Phillips, J. (2008). Embedding CSR values: The global footwear industry's evolving governance structure. Journal of Business Ethics, 81(1), 143-156.

Locke, R. M., Qin, F. E. I., \& Brause, A. (2007). Does monitoring improve labor standards? Lessons from Nike. Industrial and Labor Relations Review, 61(1), 3-31.

Lund-Thomsen, P. (2008). The global sourcing and codes of conduct debate: Five myths and five recommendations. Development and Change, 39(6), 1005-1018.

Lund-Thomsen, P., \& Lindgreen, A. (2014). Corporate social responsibility in global value chains: Where are we now and where are we going? Journal of Business Ethics, 123, 11-22.

Marwell, G., \& Oliver, P. (1993). The critical mass in collective action: A micro-social theory. New York: Cambridge University Press.

Miles, M. B., \& Huberman, A. M. (1994). Qualitative data analysis: An expanded sourcebook. Thousand Oaks, CA: Sage.

Morali, O., \& Searcy, C. (2012). A review of sustainable supply chain management practices in Canada. Journal of Business Ethics, $117(3), 635-658$ 
Morgan, R. M., \& Hunt, S. D. (1994). The commitment-trust theory of relationship marketing. Journal of Marketing, 58, 20-38.

Murphy, D., \& Matthew, D. (2001). Nike and global labour practices. A case study prepared for the New Academy of Business Innovation Network for Socially Responsible Business. Bristol: New Academy of Business.

Neef, D. (2004). The supply chain imperative: How to ensure ethical behavior in your global suppliers. New York: AMACOM.

Nelson, J., \& Zadek, S. (2000). Partnership alchemy: New social partnerships in Europe. Copenhagen: The Copenhagen Centre.

Nooteboom, B. (2004). Inter-firm collaboration, learning and networks: An integrated approach. London: Psychology Press.

O'Rourke, D. (2006). Multi-stakeholder regulation: Privatizing or socializing global labor standards? World Development, 34(5), 899-918.

Park-Poaps, H., \& Rees, K. (2010). Stakeholder forces of socially responsible supply chain management orientation. Journal of Business Ethics, 92(2), 305-322.

Patton, M. (1990). Qualitative evaluation and research methods. Sage. Beverly Hills, CA: Sage.

Pedersen, E. R. (2006). Making corporate social responsibility (CSR) operable: How companies translate stakeholder dialogue into practice. Business and Society Review, 111(2), 137-163.

Pedersen, E. R., \& Andersen, M. (2006). Safeguarding corporate social responsibility (CSR) in global supply chains: How codes of conduct are managed in buyer-supplier relationships. Journal of Public Affairs, 6, 228-240.

Plambeck, E. L., \& Taylor, T. A. (2016). Supplier evasion of a buyer's audit: Implications for motivating supplier social and environmental responsibility. Manufacturing \& Service Operations Management, 18(2), 184-197.

Podsakoff, P. M., MacKenzie, S. B., \& Podsakoff, N. P. (2012). Sources of method bias in social science research and recommendations on how to control it. Annual Review of Psychology, 63, 539-569.

Prakash, A., \& Potoski, M. (2007). Collective action through voluntary environmental programs: A club theory perspective. Policy Studies Journal, 35(4), 773-792.

Rasche, A. (2010). The limits of corporate responsibility standards. Business Ethics, 19(3), 280-291.

Rasche, A. (2012). Global policies and local practice: Loose and tight couplings in multi-stakeholder initiatives. Business Ethics Quarterly, 22(4), 679-708.

Reinecke, J., \& Donaghey, J. (2015). After rana plaza: Building coalitional power for labour rights between unions and (consumption-based) social movement organisations. Organization, 22(5), 720-740.

Rivera-Santos, M., \& Rufín, C. (2010). Odd couples: Understanding the governance of Firm-NGO alliances. Journal of Business Ethics, 94, 55-70.

Roberts, S. (2003). Supply chain specific? Understanding the patchy success of ethical sourcing initiatives. Journal of Business Ethics, $44,159-170$.

Rondinelli, D. A., \& London, T. (2003). How corporations and environmental groups cooperate: Assessing cross-sector alliances and collaborations. Academy of Management Executive, 17(1), 61-76.

Sedex. (2017). Sedex annual review 2017. Available at https://cdn. sedexglobal.com/wp-content/uploads/2018/09/Sedex-Annua 1-Review-high-res.pdf. Accessed 14 June 2019.

Soundararajan, V., \& Brown, J. A. (2016). Voluntary governance mechanisms in global supply chains: Beyond CSR to a stakeholder utility perspective. Journal of Business Ethics, 134, 83-102.

Utting, P. (2002). Regulating business via multi-stakeholders initiatives: A preliminary assessment. Geneva: United Nations Research Institute for Social Development.

Uzzi, B. (1997). Social structure and competition in interfirm networks: The paradox of embeddedness. Administrative Science Quarterly, 42(1), 35-67.

Van Tulder, R., \& Kolk, A. (2001). Multinationality and corporate ethics: Codes of conduct in the sporting goods industry. Journal of International Business Studies, 32(2), 267-283.

Vogel, D. (2008). Private global business regulation. Annual Review of Political Science, 11(1), 261-282.

Wan, Z., \& Wu, B. (2017). When suppliers climb the value chain: A theory of value distribution in vertical relationship. Management Science, 63(2), 477-496.

Wieland, B. A., \& Handfield, R. (2013). The socially responsible supply chain: An imperative for global corporations. Supply Chain Management Review, 17(5), 22-29.

Wootliff, J., \& Deri, C. (2001). NGOs: The new super brands. Corporate Reputation Review, 4(2), 157-164.

Publisher's Note Springer Nature remains neutral with regard to jurisdictional claims in published maps and institutional affiliations. 